University of Nebraska - Lincoln

DigitalCommons@University of Nebraska - Lincoln

Natural enemies of the Coccinellidae: Parasites, pathogens, and parasitoids

\author{
E. W. Riddick
}

USDA-ARS

T. E. Cottrell

USDA-ARS

K. A. Kidd

North Carolina Dept. of Ag. \& Cons. Services

Follow this and additional works at: https://digitalcommons.unl.edu/usdaarsfacpub

Part of the Agricultural Science Commons

Riddick, E. W.; Cottrell, T. E.; and Kidd, K. A., "Natural enemies of the Coccinellidae: Parasites, pathogens, and parasitoids" (2009). Publications from USDA-ARS / UNL Faculty. 374.

https://digitalcommons.unl.edu/usdaarsfacpub/374

This Article is brought to you for free and open access by the U.S. Department of Agriculture: Agricultural Research Service, Lincoln, Nebraska at DigitalCommons@University of Nebraska - Lincoln. It has been accepted for inclusion in Publications from USDA-ARS / UNL Faculty by an authorized administrator of DigitalCommons@University of Nebraska - Lincoln. 
Review

\title{
Natural enemies of the Coccinellidae: Parasites, pathogens, and parasitoids
}

\author{
E.W. Riddick ${ }^{\mathrm{a}, *}$, T.E. Cottrell ${ }^{\mathrm{b}}$, K.A. Kidd ${ }^{\mathrm{c}}$ \\ a USDA-ARS, 59 Lee Road, Stoneville, MS 38776, USA \\ ${ }^{\mathrm{b}}$ USDA-ARS, 21 Dunbar Road, Byron, GA 31008, USA \\ ${ }^{\mathrm{c}}$ North Carolina Dept. of Ag. E' Cons. Services, 950 E. Chatham Street, Cary, NC 27511, USA
}

\section{A R T I C L E I N F O}

\section{Article history:}

Received 6 January 2009

Accepted 26 May 2009

Available online 30 May 2009

\section{Keywords:}

Beauveria bassiana

Coccipolipus hippodamiae

Dinocampus coccinellae

Hesperomyces virescens

Pediobius foveolatus

Population dynamics

\begin{abstract}
A B S T R A C T
We review aspects of the life histories of representative enemies of coccinellids (both entomophagous and phytophagous species) and expose both potential and real effects that they have on life parameters of their hosts. Lady beetles are attacked by a variety of natural enemies (bacteria, fungi, mites, nematodes, protozoa, wasps, flies). Few of these enemies have the ability to alter significantly the population dynamics of their hosts. This review should encourage further research to help define the role of natural enemies in the population dynamics of coccinellids. Ultimately, the conservation of beneficial lady beetles and the management of nuisance and pestiferous ones should be major emphases of research on coccinellid-natural enemy interactions.
\end{abstract}

Published by Elsevier Inc.

\section{Introduction}

Although knowledge of naturally occurring parasites, pathogens, and parasitoids of coccinellids has increased in recent years, a limited number of studies have investigated the biology and ecology of those species that attack beneficial lady beetles, which often contribute to the reduction of herbivore populations in managed and unmanaged ecosystems. Recent advances have been made in the biology of dipteran and hymenopteran parasitoids of coccinellids (Nalepa et al., 1996; Disney, 1997; Hoogendoorn and Heimpel, 2002; Nalepa and Kidd, 2002; Firlej et al., 2005; Koyama and Majerus, 2008), as well as pathogenic bacteria (Majerus et al., 1998), pathogenic fungi (Cottrell and ShapiroIlan, 2003, 2008; Roy et al., 2008), and nematodes (Shapiro-Ilan and Cottrell, 2005). However, the biology and ecology of viruses, nematodes, mites, and fungi that attack coccinellids are largely unknown. Here we emphasize the primary literature published since the excellent review of coccinellid natural enemies by Ceryngier and Hodek (1996), and some pre-1996 literature that was omitted from this earlier review. In addition, the literature was searched to determine whether any enemy demonstrated the potential of regulating the population dynamics of any coccinellid species.

\footnotetext{
* Corresponding author. Address: Biological Control of Pests Research Unit, National Biological Control Laboratory, USDA-ARS, Mid-South Area, P.O. Box 67, 59 Lee Road, Stoneville, MS 38776, USA. Fax: +1 6623126096.
}

\section{Parasites}

Parasites of lady beetles can be loosely grouped as endo- and ectoparasites. Ceryngier and Hodek (1996) reviewed roundworms (Nematoda: families Allantonematidae and Mermithidae) as endoparasites of the adult stage of entomophagous lady beetles in Europe. Raju and Uma Maheswari (2005) reported a Mermis sp. (Mermithidae) from fourth instars of a phytophagous lady beetle, Henosepilachna vigintioctopunctata $\mathrm{F}$., in India. Ectoparasitic fungi (order Laboulbeniales, family Laboulbeniaceae) and ectoparasitic mites (order Acarina, family Podapolipidae) have been found on coccinellids throughout the world. The parasitic fungi and mites will be reviewed in the following paragraphs.

\subsection{Parasitic fungi}

The order Laboulbeniales contains ascomycetous fungi that parasitize arthropods. Approximately $80 \%$ of the 2000 described laboulbenialean species include beetles as their hosts (Santamaria, 2001; Weir and Blackwell, 2004). As far as is known, all Laboulbeniales are biotrophic; that is, they require a living host for continued survival and propagation. Horizontal transmission of Laboulbeniales, likely through direct contact between adult hosts, is the common mode of perpetuation. This process is greatly facilitated when coccinellid hosts aggregate at feeding or overwintering sites (Welch et al., 2001; Riddick and Schaefer, 2005; Riddick, 2006; Nalepa and Weir, 2007). The propensity of entomophagous males to repeatedly attempt to copulate with con- and heterospecific males and females under field conditions may facilitate the 
spread of laboulbenialean fungi through populations of susceptible species. Four Laboulbeniales species within the genus Hesperomyces Thaxter attack entomophagous lady beetles (Table 1). Hesperomyces virescens Thaxter has multiple hosts including Harmonia axyridis (Pallas). Whether $H$. virescens can develop and thrive on phytophagous coccinellids is unknown.

Tavares (1979) and Weir and Beakes (1995) claim that most Laboulbeniales species are avirulent and cause little harm to their hosts. However, Kamburov et al. (1967) reported that $H$. virescens caused premature mortality when it infected up to $95 \%$ of the adults of the coccinellid Chilocorus bipustulatus in Israel (but see Applebaum et al., 1971). Numerous $H$. virescens thalli concentrated around the host's (H. axyridis) mouthparts, head or antennae, can hamper the detection of food, mates or predators (Nalepa and Weir, 2007). Additionally, infected females mate less frequently (Nalepa and Weir, 2007). Apparently, there is little evidence to suggest that laboulbenialean parasites have significant effects on coccinellid populations.

\subsection{Parasitic mites}

Acarine parasites in the family Podapolipidae are biotrophic and commonly attack beetles. Although most species live ectoparasitically underneath the elytra of their hosts, some are endoparasites found in host reproductive organs or tracheal systems (Hajiqanbar et al., 2007). Their horizontal transmission is greatly facilitated via social contact between mating (Knell and Webberley, 2004) or overwintering coccinellid hosts (Webberley and Hurst, 2002).

The 14 species that attack lady beetles are confined to the genus Coccipolipus (Husband, 1984; Ceryngier and Hodek, 1996). Husband (1984) stated that some mite species may be quite specific within a host clade. For example, Coccipolipus chilocori Husband has been discovered attacking five central African Chilocorus species, but not other sympatric coccinellids. Most Coccipolipus species appear to attack within Coccinellinae, Epilachninae, and Chilocorinae. No species in Coccidulinae, Sticholotidinae, or Scymninae are known hosts of Coccipolipus. Several additional parasite-host associations have been reported recently for two widely distributed mites, Coccipolipus macfarlanei Husband and Coccipolipus hippodamiae McDaniel and Morrill. Coccipolipus macfarlanei was found on Coccinella septempunctata L. and on Coccinella undecimpunctata L. in Iran (Hajiqanbar et al., 2007). Coccipolipus (Tetrapolipus) hippodamiae was recently found attacking several coccinellids in
Europe, including Adalia decempunctata (L.), Synharmonia conglobata (L.), and Calvia quatuordecimguttata (L.) (Webberley et al., 2004).

Most species are considered avirulent, having little or no impact on the population dynamics of their hosts (Knell and Webberley, 2004). Coccipolipus epilachnae Smiley parasitizes phytophagous coccinellids such as the Mexican bean beetle Epilachna varivestis Mulsant (Epilachninae) (Schroder, 1979, 1982). However, the ability of $C$. epilachnae to suppress $E$. varivestis populations is doubtful (Cantwell et al., 1985; Hochmuth et al., 1987). The effects of $C$. hippodamiae on entomophagous coccinellids in Europe have been recently described. The fecundity and egg viability of three coccinellids, Adalia bipunctata, A. decempunctata, and S. conglobata, were significantly reduced by $C$. hippodamiae (Hurst et al., 1995; Webberley et al., 2004). This mite also increased overwintering mortality of $A$. bipunctata males (Webberley and Hurst, 2002; Webberley et al., 2006). Recently, Kenis et al. (2008) proposed the use of $C$. hippodamiae as a biocontrol agent within an integrated pest management program against the nuisance coccinellid, $H$. axyridis. Before this occurs, a risk assessment on the non-target implications of releasing this polyphagous mite seems warranted. As part of this risk assessment, the potential efficacy of the mite on $H$. axyridis fitness should be considered.

\section{Pathogens}

Ceryngier and Hodek (1996) commented that microorganisms attacking Coccinellidae are not well known, and this is still true today (Roy and Cottrell, 2008). As a whole, research on the natural interaction of coccinellids and their pathogens (as with the pathogens of most natural enemies) has received less attention than the pathogens of herbivorous pests, and most research concerns nontarget effects of biorational insecticides on coccinellids. This notwithstanding, attention to recent advances in male-killing bacteria, fungi, and microsporidia merit discussion.

\subsection{Viruses}

No reports of viral infection in entomophagous Coccinellidae could be found. Kitajima et al. (1985) reported the presence of Reovirus-like particles from the phytophagous $E$. varivestis. These apparently latent, virus-like particles were found in nurse cells of the ovariole, oocytes, egg cytoplasm, and sperm nuclei. This

Table 1

Parasitic Laboulbeniales of the genus Hesperomyces and their lady beetle hosts.

\begin{tabular}{|c|c|c|}
\hline Hesperomyces species & Hosts and distribution & References \\
\hline H. chilomenis (Thaxter) & Cheilomenes lunata (East Africa) & Thaxter (1931) \\
\hline \multirow[t]{4}{*}{ H. coccinelloides (Thaxter) } & Scymnus sp. (West Indies) & Thaxter (1931) \\
\hline & Scymmus tardus (West Indies) & Thaxter (1931) \\
\hline & Scymmus sp. (Spain) & Santamaria (1995) \\
\hline & Diomus sp. (Ecuador) & Castro and Rossi (2008) \\
\hline H. hyperaspidis Thaxter & Hyperaspis sp. (West Indies) & Thaxter (1931) \\
\hline \multirow{13}{*}{$H$. virescens Thaxter } & Chilocorus stigma (USA) & Thaxter (1931) \\
\hline & Hippodamia convergens (USA) & Thaxter (1931) \\
\hline & Eriopis connexa (Argentina) & Thaxter (1931) \\
\hline & Chilocorus bipustulatus (Israel) & Kamburov et al. (1967) \\
\hline & Cycloneda sanguinea (England) & Tavares (1979) \\
\hline & Psyllobora (= Thea) sp. (France) & Tavares (1985) \\
\hline & Adalia bipunctata (southern Europe) & Weir (1996) \\
\hline & Olla $v$-nigrum (Fiji) & Weir and Beakes (1996) \\
\hline & Harmonia axyridis (USA) & Garcés and Williams (2004) \\
\hline & Coccinella septempunctata (USA) & Harwood et al. (2006a) \\
\hline & Cycloneda munda (USA) & Harwood et al. (2006b) \\
\hline & Brachiacantha quadripunctata (USA) & Harwood et al. (2006b) \\
\hline & Psyllobora vigintimaculata (USA) & Harwood et al. (2006b) \\
\hline
\end{tabular}


suspected virus is thought to be transmitted vertically. Viruses infecting coccinellids are likely chronic and asymptomatic.

\subsection{Protozoa: microsporidia and eugregarines}

Brooks et al. (1980) reported gradual decimation of an $E$. varivestis colony that had nearly $100 \%$ microsporidiosis caused by Nosema epilachnae Brooks, Hazard and Becnel and N. varivestis Brooks, Hazard and Becnel (Brooks et al., 1985). Mechanical transmission of $N$. epilachnae and $N$. varivestis between diseased and healthy $E$. varivestis is possible through oviposition by the parasitoid Pediobius foveolatus (Crawford) (Hymenoptera: Eulophidae); $P$. foveolatus is highly susceptible to $N$. epilachnae and $N$. varivestis (Own and Brooks, 1986). Parasitoid females infected with $N$. varivestis were capable of transmitting this pathogen transovarially to $F_{6}$ progeny at rates ranging from $6 \%$ to $70 \%$ (Own and Brooks, 1986). The ability of $P$. foveolatus to facilitate transmission of the pathogen to a shared host may or may not further suppress E. varivestis populations.

Bjørnson (2008) reported that $0.9 \%$ of winter-collected Hippodamia convergens adults (purchased from commercial suppliers) were infected with microsporidia, most likely Nosema hippodamiae Lipa \& Steinhaus, N. tracheophila Cali \& Briggs, and N. coccinellae Lipa. Joudrey and Bjørnson (2007) found that infection reduced longevity and increased development rates of $H$. convergens. Both vertical and horizontal transmission of spores can be highly efficient. Saito and Bjørnson (2006) reported 100\% horizontal transmission of an unidentified microsporidium from $H$. convergens to larval C. septempunctata, Coccinella trifasciata perplexa Mulsant, and $H$. axyridis when these larvae consumed infected $H$. convergens eggs. Thus, human redistribution of $H$. convergens for aphid control outside of its native range may introduce new microsporidia to previously unexposed coccinellid species. Interestingly, of the coccinellids tested for horizontal transmission, invasive species may be less affected by microsporidian infection than native ones (Saito and Bjørnson, 2006, 2008).

Eugregarine protozoans (Apicomplexa: Gregarinia: Eugregarinida) are mostly pathogens of annelids and arthropods, but some are commensals or even mutualists. They are extracellular and are found in the digestive tracts and body cavities of hosts (Tanada and Kaya, 1993). Bjørnson (2008) reported that $0.2 \%$ of winter-collected $H$. convergens purchased from commercial suppliers were infected with eugregarines. Three different-sized eugregarines were collected, but none were identified. Saito and Bjørnson (2008) found three unidentified eugregarines in two A. bipunctata adults. These protozoans probably have little impact on populations of entomophagous coccinellids. Eugregarine protozoans of phytophagous species are not reported.

\subsection{Fungi}

Field data on the impact of natural fungal pathogens attacking coccinellids is limited but suggests that natural infection levels are less than 20\% (Ceryngier, 2000; Beyene et al., 2007). Beauveria bassiana (Balsamo) (Ascomycota: Hypocreales: Clavicipitaceae) is a generalist pathogen most often reported infecting phytophagous (Uma Devi et al., 2008) and entomophagous (Roy and Cottrell, 2008) coccinellids. Larvae of the phytophagous Epilachna vigintioctopunctata $\mathrm{F}$. and Henosepilachna vigintioctomaculata (Motschulsky) are susceptible to B. bassiana (Kuznetsov, 1997; Uma Devi et al., 2008). Even though $H$. vigintioctomaculata field populations were decimated by fungal pathogens during the 1960 s, only about $6 \%$ of $H$. vigintioctomaculata were found infected in the field at two subsequent points in time (Kuznetsov, 1997).

Field observations by Cottrell and Shapiro-Ilan (2003) led to a series of experiments testing an apparent endemic $B$. bassiana against native and exotic entomophagous coccinellids. This B. bassiana was collected from small aggregations of overwintering Olla $v$-nigrum Mulsant under tree bark where some dead individuals exhibited B. bassiana mycosis. However, B. bassiana infection also was detectable on non-overwintering $0 . v$-nigrum during the spring and fall with $4 \%$ and $38 \%$ mycosis, respectively. Harmonia axyridis collected from the same habitats and at the same time as $O$. v-nigrum had low mortality and none were infected with $B$. bassiana indicating possible differential susceptibility between this introduced species and the native $O . v$-nigrum. Summer collections of both species from the same vicinity five years later revealed the same trend with $9 \%$ of $O$. $v$-nigrum having B. bassiana mycosis but none for $H$. axyridis (TEC, unpublished data). Thus, specific strains of $B$. bassiana may be better-adapted to infecting certain native species as shown by Cottrell and Shapiro-Ilan (2003, 2008). They documented that isolates of $B$. bassiana, from naturally infected O. $v$-nigrum, were pathogenic to the native species $0 . v$-nigrum, $C$. munda, and $H$. convergens but not to the native $C$. maculata or the exotic $H$. axyridis. Their studies used much lower conidia rates (i.e., the predetermined $\mathrm{LC}_{50}$ of $2.5 \times 10^{5}$ conidia/ml against $O$. $v$ nigrum) in their assays compared with studies that assay non-target impacts of fungal products using from $10^{7}$ to $10^{9}$ conidia $/ \mathrm{ml}$ (Haseeb and Murad, 1997; James et al., 1998; Poprawski et al., 1998; Cagáň and Uhlík, 1999; Todorova et al., 2000). When noncoccinellid sources of $B$. bassiana (i.e., strain GHA and BbAR1) were tested at $2.5 \times 10^{5}$ conidia/ml, there was little activity against $C$. maculata, C. munda, $\mathrm{H}$. convergens, or O. v-nigrum (Cottrell and Shapiro-Ilan, 2008). In another example of differential susceptibility among species, Todorova et al. (2000) found that C. maculata was differentially susceptible to B. bassiana isolates. Susceptibility depends on rates of inoculum; for example, Roy et al. (2008) used high rates of $B$. bassiana (strain GHA) conidia $\left(>10^{8}\right.$ per $\mathrm{ml}$ ) to achieve an $\mathrm{LD}_{50}$ against $H$. axyridis in contrast to rates used by Cottrell and Shapiro-Ilan (2003). It is probable that $H$. axyridis is resistant to endemic $B$. bassiana within introduced regions, as demonstrated by Cottrell and Shapiro-Ilan (2003, 2008); but within its native range, Kuznetsov (1997) reports that $H$. axyridis was found naturally infected by Beauveria spp. Coccinellid mortality resulting from $B$. bassiana infection does occur naturally but has not clearly been shown to regulate populations.

Fungi other than B. bassiana are also reported from Coccinellidae (Bjørnson, 2008). Ceryngier (2000) found overwintering populations of $C$. septempunctata in Poland also infected by Paecilomyces farinosus (Holm \& Gray), Verticillium lecanii (Zimmerman), and Cephalosporium sp. Both V. lecanii and Cephalosporium sp. were found to be weak pathogens, whereas $P$. farinosus was intermediate and $B$. bassiana was highly virulent against $C$. septempunctata. Although two species of Metarhizium are used widely, there is surprisingly little information on their impact on coccinellid populations (but see Peveling and Demba, 1997; Ginsberg et al., 2002).

\subsection{Bacteria}

Most studies on bacterial infections of Coccinellidae concern male-killing bacteria (Hurst et al., 1994, 1996, 1997, 1999a,b,c; Majerus et al., 1998, 2000b; Majerus and Majerus, 2000; Schulenburg et al., 2001; Sokolova et al., 2002; Dyson and Hurst, 2004; Nakamura et al., 2005). Male-killing agents include Rickettsia, Spiroplasma, Wolbachia, Flavobacteria, $\gamma$-proteobacterium, and some yet to be identified agents (Majerus, 2006). Maternally inherited bacteria kill males during early embryogenesis, and infection provides an adaptive advantage for female offspring that feed on unhatched male eggs. Entomophagous species infected by one or more of these agents are in the genus Adalia, Adonia, Anisosticta, Calvia, Cheilomenes, Coccinella, Coccinula, Coleomegilla, Harmonia, Hippodamia, and Propylea from Africa, Asia, Europe, and North 
America (Majerus, 2006). Coccinellids are not only affected by male-killing bacteria. Hall and Badgley (1957) implicate an infection of Rickettsiella stethorae as killing the larvae of five cultured Stethorus spp.

A few reports indicate that phytophagous coccinellids are attacked by bacteria. Ping et al. (2008) reported that a WZ-9 strain of Bacillus thuringiensis Berliner was harmful to $\mathrm{H}$. vigintioctomaculata larvae but not adults. The $\mathrm{LC}_{50}$ to second instars was $2.95 \times 10^{7}$ cells $/ \mathrm{ml}$ after $72 \mathrm{~h}$. Otsu et al. (2003) reported that the chitinase secreting strain (KPM-012A) of the bacteria Alcaligenes paradoxus Davis had a suppressive effect on E. vigintioctopunctata adults. A suspension of $A$. paradoxus (entrapped in alginate beads) inhibited feeding and oviposition but had no effect on longevity of E. vigintioctopunctata.

\subsection{Nematodes}

Unlike endoparasitic nematodes, the entomopathogenic Steinernema and Heterorhabditis nematode spp. can be highly virulent to susceptible hosts causing death within $24-48 \mathrm{~h}$ after initial infection. Shapiro-Ilan and Cottrell (2005) reported lower susceptibility for both the exotic $H$. axyridis and $C$. septempunctata than for the native $C$. maculata and $O$. $v$-nigrum to the nematodes Steinernema carpocapsae (Weiser) and Heterorhabditis bacteriophora Poinar. Given their foraging ecology, it seems unlikely that entomophagous coccinellids will be frequent hosts of soil-borne entomopathogenic nematodes. Abdel-Moniem and Gesraha (2001) reported that fourth instar larvae of the phytophagous Epilachna chrysomelina F. experienced $65 \%, 44 \%$, and $84 \%$ mortality when exposed to squash seedlings treated with formulations of Heterorhabditis taysearae Shamseldean, H. bacteriophora (strain Hp88), and S. carpocapsae (strain $\mathrm{S} 2$ ), respectively.

\section{Parasitoids}

Coccinellids are attacked in all life stages by nearly 100 species of parasitoids, which primarily belong to the orders Hymenoptera and Diptera (Ceryngier and Hodek, 1996). Most reports are host records with scant data on population dynamics or ecological impact.

\subsection{Hymenopterous parasitoids of phytophagous coccinellids}

The effects of parasitoids on populations of phytophagous Epilachninae have been documented more often than on entomophagous species. In the eastern USA, augmentative releases of $P$. foveolatus have been used to provide control of $E$. varivestis on soybeans and other legume plantings (Fess, 2008). Pediobius foveolatus provides control of the introduced Epilachna viginsexpunctata (Boisduval) feeding on solanaceous crops in Guam. Although the beetle remains present, $P$. foveolatus also persists, reducing the need for additional control measures (Vargo and Schreiner, 2000). Parasitoids commonly attack immature life stages of Henosepilachna viginitioctopunctata F. on Solanum melongena (brinjal/eggplant) in India where parasitism rates vary over the year, but can approach substantial reductions (as high as 38\% of eggs and 68\% of larvae) (Raju and Uma Maheswari, 2005; Hussain et al., 2006).

Parasitoids may not provide economic control, in spite of high parasitism rates of phytophagous coccinellids. In Ethiopia, although the egg parasitoid Ooencyrtus epulus Annecke (Hymenoptera: Encyrtidae) and the pupal parasitoids P. foveolatus and Mesopolobus sp. (Hymenoptera: Pteromalidae) were key mortality factors of Chnootriba similis, the parasitoids did not reduce pest populations below economically damaging levels (Beyene et al., 2007). Similarly, in Indonesia, 36\% egg parasitism by Tetrastichus sp. against Epilachna sp. nr. sparsa (Herbst) was not sufficient to prevent lethal defoliation of Momordica charntia (bitter cucumber) (Abbas and Nakamura, 1985).

\subsection{Hymenopterous parasitoids of entomophagous coccinellids}

Few parasitoids of entomophagous coccinellids are specialists, some are widely distributed and attack within a subfamily or tribe. One of the best understood parasitoids is Dinocampus (Perilitus) coccinellae Schrank (Hymenoptera: Braconidae), whose host preference, life history, ecology, and behavior have been thoroughly investigated (Ceryngier and Hodek, 1996; Majerus, 1997; Majerus et al., 2000a; Okuda and Ceryngier, 2000; Al Abassi et al., 2001; Davis et al., 2006; Firlej et al., 2006; Koyama and Majerus, 2008). Adult coccinellids are preferred, especially older females (Majerus et al., 2000a; Davis et al., 2006), but immature parasitoids have been found in host larvae and pupae (Geoghegan et al., 1998). As a solitary endoparasitoid of adults, $D$. coccinellae prefers larger species of Coccinellinae (Ceryngier and Hodek, 1996). Coccinellids vary in their suitability as hosts for $D$. coccinellae (Orr et al., 1992; Firlej et al., 2006; Koyama and Majerus, 2008), but the mechanisms that influence realized rates of parasitism of various coccinellid species are unknown for many species. Comparing primary and secondary parasitism rates suggests that at least some coccinellids are able to overcome parasitoid larvae (Hoogendoorn and Heimpel, 2002; Koyama and Majerus, 2008). Although much of the biology of $D$. coccinellae has been determined in the laboratory, further field studies on its impact on population dynamics and ecology of coccinellid communities are warranted. This is especially true when exotic species invade new biotas where they alter coccinellid communities.

A number of other Hymenoptera are larval or larval/pupal parasitoids of entomophagous coccinellids. Oomyzus scaposus (Thomson) (Hymenoptera: Eulophidae) is a widely distributed gregarious parasitoid of coccinellids. It has a wide host range that includes Coccinellinae, Chilocorinae, and Scymninae (Ceryngier and Hodek, 1996), including H. axyridis (Kuznetsov, 1997). Females lay eggs in third and fourth instars, and adult wasps emerge from pupal mummies. Forty-four percent of $48 \mathrm{H}$. axyridis pupae collected in North Carolina, USA, were parasitized by 0 . scaposus (KAK, unpublished data). Other parasitoids present were Homalotylus terminalis (Say) (Hymenoptera: Encyrtidae), Aprostocetus neglectus (Domenichini) (Hymenoptera: Eulophidae), and Pachyneuron altiscutum Cook (Hymenoptera: Pteromalidae). Several species of the genus Homalotylus have been recorded as parasitoids of coccinellid larvae in the subfamilies Coccinellinae, Chilocorinae, and Scymninae (Ceryngier and Hodek, 1996). Many have wide host ranges and the rate of parasitism can reach $90-95 \%$ within a population (Ceryngier and Hodek, 1996; Kenis et al., 2008). Aprostocetus neglectus specializes on hosts in the subfamily Chilocorinae in Eurasia, North Africa and North America (Ceryngier and Hodek, 1996). In eastern North America A. neglectus attacks Chilocorus kuwanae (Silvestri), which was imported for biological control of euonymus scale Unaspis euonymi (Comstock) (Nalepa et al., 1993; Matadha et al., 2003), although the implications of this parasitoid for North American chilocorines are largely unknown.

\subsection{Dipteran parasitoids of phytophagous and entomophagous coccinellids}

Strongygaster triangulifer (Loew) (Diptera: Tachinidae) is common in North America and has been found in coccinellids and a variety of other adult Coleoptera and numerous other insect orders. This tachinid exploits novel hosts, but because it attacks low numbers within a population (usually less than 10\%) it is not likely a key mortality factor for any of its coccinellid hosts. Smith 
and Kok (1983) noted that of 20 reported hosts of S. triangulifer in North America, nine were introduced species.

Strongygaster triangulifer parasitizes the phytophagous Epilachna spp., including E. varivestis, as well as several species of entomophagous Coccinellinae (Katsoyannos and Aliniazee, 1998; Nalepa and Kidd, 2002). In North Carolina, aggregating H. axyridis were sampled for parasitoids over seven years (Nalepa and Kidd, 2002). In 1992, parasitism in aggregating beetles averaged $14.2 \%$ (range, 3-31\%) but dropped below 5\% for each of the next six years (Nalepa and Kidd, 2002) and does not regulate the populations (Koch and Galvan, 2008; KAK, unpublished data). Similarly, 15.4\% and $11.4 \%$ of overwintering $H$. axyridis were parasitized by $S$. triangulifer in Oregon, USA during 1997 (Katsoyannos and Aliniazee, 1998).

Dipteran pupal parasitoids in the family Phoridae attack entomophagous coccinellids in Europe and Asia (Ceryngier and Hodek, 1996). Two common species, Phalacrotophora berolinensis Schmitz and $P$. fasciata Fallen, parasitize up to $80 \%$ of individuals of some species of Coccinellinae and Chilocorinae (Ceryngier and Hodek, 1996; Hurst et al., 1998). Osawa (1992) reared Phalacrotophora sp. from $17.7 \%$ of $249 \mathrm{H}$. axyridis pupae collected in Japan. In another year, about $10 \%$ of pupae were parasitized (Osawa, 1992). Phalacrotophora beuki Disney appears to be a specialist of Anatis ocellata (L.) in Scots pine forests in central Poland (Durska et al., 2003). From $35 \%$ to $40 \%$ of $A$. ocellata pupae were parasitized by $P$. beuki in samples collected from 1998 to 2000 (Durska et al., 2003). Phalacrotophora philaxyridis Disney parasitized $H$. axyridis in Japan, but additional work on host range is necessary before this can be a viable candidate for biological control of $H$. axyridis (Kenis et al., 2008).

\section{Concluding remarks}

Differences in the behavior, biology, and ecology of phytophagous versus entomophagous coccinellids may affect attack by natural enemies. Typically sedentary and found on fewer plant species, phytophagous species contrast with highly mobile entomophagous species found on many plant species. Thus, increased mobility and dispersal of entomophagous species could decrease efficiency of host finding by parasitoids and increase the need for parasitoids to attack several host species. Field epizootics within the Coccinellidae are not known, but clumped field populations of phytophagous coccinellids may be subject to conditions favorable for the development of epizootics. Some entomophagous species congregate to overwinter, thereby increasing transmission of pathogens and parasites. The propensity of entomophagous males to repeatedly attempt to copulate with con- and heterospecific males and females under field conditions may facilitate the spread of parasitic fungi and mites through populations of susceptible species.

The role that natural enemies play in the population dynamics of the Coccinellidae needs to be better defined for both entomophagous and phytophagous species. The inability of natural enemies to regulate coccinellid populations was reported by Hodek (1973) and reiterated by Majerus (1994) and Ceryngier and Hodek (1996). Overall, current research has not demonstrated otherwise except that one parasitoid wasp ( $P$. foveolatus) apparently has the potential to alter the population dynamics of a phytophagous coccinellid (Vargo and Schreiner, 2000). The ability of $P$. foveolatus to facilitate transmission of a microsporidian ( $N$. varivestis) to a shared host (Own and Brooks, 1986) may or may not further suppress host populations. One parasitoid fly ( $P$. beuki) may have the potential to limit populations of an entomophagous coccinellid in pine forests (Durska et al., 2003), but further host specificity testing is necessary. Ectoparasitic fungi or ectoparasitic mites are not likely to alter the population dynamics of their coccinellid hosts. Nevertheless, an ectoparasitic mite ( $C$. epilachnae) has been considered as a potential biological control agent of a phytophagous coccinellid (Schroder, 1982). Recently, an ectoparasitic mite (C. hippodamiae) has been identified that might aid in the suppression of populations of an invasive entomophagous coccinellid (H. axyridis) within an IPM framework (Kenis et al., 2008). A research program to address this proposition is needed but is complicated given the value of $H$. axyridis as an important predator of sternorrhynchan pests in agricultural landscapes and the low host specialization of the mite.

More research is necessary to determine the capacity of coccinellids to defend themselves against attack from their natural enemies. Coccinellids rely heavily on chemical defense (commonly accompanied by warning coloration) to thwart attacks from vertebrate and invertebrate predators (Majerus et al., 2007; Pasteels, 2007). The role of defensive compounds in protection of coccinellids against parasites, pathogens, and parasitoids remains largely unknown. A variety of parasitoids are found attacking different life stages of coccinellids in spite of their many defense mechanisms. In fact, one species (D. coccinellae) uses the defensive compounds of its host as a kairomone (Al Abassi et al., 2001). The ability to mount a humoral or cellular immune response against their enemies has not been demonstrated for most species.

Most reports of parasitoids present only a host record with little data about the impact on populations of entomophagous species and, by extension, their impact on the benefit provided by these coccinellids as biological control agents. Many of the parasitoids have broad host ranges or in some cases are restricted to attacking many members of a single tribe or subfamily. This is advantageous for parasitoids of Epilachninae because all of these species are phytophagous and many are economically important crop pests. Further research is needed to understand the impact of native parasitoids on introduced entomophagous coccinellids, such as $H$. axyridis and C. septempunctata.

Protocols for pre-release tests of field-collected lady beetles are needed. Each year countless $H$. convergens adults are harvested from overwintering sites in California destined for use in augmentative biological control of aphids in agriculture and home gardens in the USA and Canada (Bjørnson, 2008). This practice may result in unintended dispersal of coccinellid natural enemies outside of native ranges with unknown impacts on previously unexposed coccinellid species. Human involvement in the spread of coccinellid pathogens can undermine the success of biological control programs and the integrity of native coccinellid communities.

This review has shown that parasites, pathogens, and parasitoids have limited potential of regulating the population dynamics of coccinellids when acting alone. Perhaps, the action of multiple natural enemies acting together on the same host population could provide a greater impact on host dynamics than any one species acting alone. Finally, the benefits and limitations of incorporating effective natural enemies into an IPM framework to manage pestiferous and nuisance coccinellids need to be assessed.

\section{Acknowledgments}

Don Weber and Jonathan Lundgren reviewed and commented on an earlier version of this manuscript. We thank J. Lundgren and D. Weber for inviting us to write this manuscript. Two anonymous reviewers provided useful comments that improved the text. The United States Government has the right to retain a non-exclusive, royalty-free license in and to any copyright of this article. This article reports the results of research only. Mention of a commercial or proprietary product does not constitute an endorsement of the product by the United States Department of Agriculture. 


\section{References}

Abbas, I., Nakamura, K., 1985. Adult population parameters and life tables of an epilachnine beetle (Coleoptera: Coccinellidae) feeding on bitter cucumber in Sumatra. Researches on Population Ecology 27, 313-324.

Abdel-Moniem, A.S.H., Gesraha, M.A., 2001. Evaluation of certain entomopathogenic nematodes against the melon ladybird, Epilachna chrysomelina F. (Coleoptera: Coccinellidae). Archives of Phytopathology and Plant Protection 34, 327-336.

Al Abassi, S., Birkett, M.A., Petterson, J., Pickett, J.A., Wadhams, L.J., Woodcock, C.M., 2001. Response of the ladybird parasitoid Dinocampus coccinellae to toxic alkaloids from the seven-spot ladybird, Coccinella septempunctata. Journal of Chemical Ecology 27, 33-43.

Applebaum, S.W., Kfir, R., Gerson, U., Tadmor, U., 1971. Studies on the summer decline of Chilocorus bipustulatus in citrus groves of Israel. Entomophaga 16, 433-444.

Beyene, Y., Hofsvang, T., Azerefegne, F., 2007. Population dynamics of tef epilachna (Chnootriba similis Thunberg) (Coleoptera: Coccinellidae) in Ethiopia. Crop Protection 26, 1634-1643.

Bjørnson, S., 2008. Natural enemies of the convergent lady beetle, Hippodamia convergens Guérin-Méneville: their inadvertent importation and potential significance for augmentative biological control. Biological Control 44, 305-311.

Brooks, W.M., Montross, D.B., Sprenkel, R.K., Carner, G., 1980. Microsporidioses of coleopterous pests of soybeans. Journal of Invertebrate Pathology 35, 93-95.

Brooks, W.M., Hazard, E.I., Becnel, J., 1985. Two new species of Nosema (Microsporida: Nosematidae) from the Mexican bean beetle Epilachna varivestis (Coleoptera: Coccinellidae). Journal of Protozoology 32, 525-535.

Cagáň, L., Uhlík, V., 1999. Pathogenicity of Beauveria bassiana strains isolated from Ostrinia nubilalis Hbn. (Lepidoptera: Pyralidae) to original host larvae and to ladybirds (Coleoptera: Coccinellidae). Plant Protection Science 35, $108-112$.

Cantwell, G.E., Cantelo, W.W., Cantwell, M.A., 1985. Effect of a parasitic mite, Coccipolipus epilachnae, on fecundity, food consumption and longevity of the Mexican bean beetle. Journal of Entomological Science 20, 199-203.

Castro, A.C.P., Rossi, W., 2008. New records of Laboulbeniales (Fungi, Ascomycota) from Ecuador. Biodiversity of South America, I. Memoirs on Biodiversity 1,1118.

Ceryngier, P., 2000. Overwintering of Coccinella septempunctata (Coleoptera: Coccinellidae) at different altitudes in the Karkonosze Mts, SW Poland. European Journal of Entomology 97, 323-328.

Ceryngier, P., Hodek, I., 1996. Enemies of the Coccinellidae. In: Hodek, I., Honk, A. (Eds.), Ecology of Coccinellidae. Kluwer Academic Publishers, Dordrecht, pp. 319-350.

Cottrell, T.E., Shapiro-Ilan, D.I., 2003. Susceptibility of a native and an exotic lady beetle (Coleoptera: Coccinellidae) to Beauveria bassiana. Journal of Invertebrate Pathology 84, 137-144.

Cottrell, T.E., Shapiro-Ilan, D.I., 2008. Susceptibility of endemic and exotic North American ladybirds (Coleoptera: Coccinellidae) to endemic fungal entomopathogens. European Journal of Entomology 105, 455-460.

Davis, D.S., Stewart, S.L., Manica, A., Majerus, M.E.N., 2006. Adaptive preferential selection of female coccinellid hosts by the parasitoid wasp Dinocampus coccinellae (Hymenoptera: Braconidae). European Journal of Entomology 103, $41-45$.

Disney, R.H.L., 1997. A new species of Phoridae (Diptera) that parasitises a widespread Asian lady beetle (Coleoptera: Coccinellidae). Entomologist 116, 163168.

Durska, E., Ceryngier, P., Disney, R.H.L., 2003. Phalacrotophora beuki (Diptera: Phoridae), a parasitoid of ladybird pupae (Coleoptera: Coccinellidae). European Journal of Entomology 100, 627-630.

Dyson, E.A., Hurst, G.D.D., 2004. Persistence of an extreme sex ratio bias in a natural population. Proceedings of the National Academy of Sciences of the United States of America 101, 6521-6525.

Fess, T.L., 2008. Organic management of Mexican bean beetle (Epilachna varivestis Mulsant) infestations in snap bean (Phaseolus vulgaris L.) crops. MS thesis, West Virginia University.

Firlej, A., Boivin, G., Lucas, E., Coderre, D., 2005. First report of Harmonia axyridis Pallas being attacked by Dinocampus coccinellae Schrank in Canada. Biological Invasions 7, 553-556.

Firlej, A., Lucas, E., Coderre, D., Boivin, G., 2006. Teratocytes growth pattern reflects host suitability in a host-parasitoid assemblage. Physiological Entomology 32, 181-187.

Garcés, S., Williams, R., 2004. First record of Hesperomyces virescens Thaxter (Laboulbeniales: Ascomycetes) on Harmonia axyridis (Pallas) (Coleoptera: Coccinellidae). Journal of the Kansas Entomological Society 77, 156-158.

Geoghegan, I.E., Majerus, T.M.O., Majerus, M.E.N., 1998. Differential parasitisation of adult and pre-imaginal Coccinella septempunctata (Coleoptera: Coccinellidae) by Dinocampus coccinellae (Hymenoptera: Braconidae). European Journal of Entomology 95, 571-579.

Ginsberg, H.S., Lebrun, R.A., Heyer, K., Zhioua, E., 2002. Potential nontarget effects of Metarhizium anisopliae (Deuteromycetes) used for biological control of ticks (Acari: Ixodidae). Environmental Entomology 31, 1191-1196.

Hajiqanbar, H., Husband, R.W., Kamali, K., Saboori, A., Kamali, H., 2007. Ovacarus longisetosus n. sp. (Acari: Podapolipidae) from Amara (Paracelia) saxicoloa Zimm. (Coleoptera: Carabidae) and new records of Coccipolipus, Dorsipes, Eutarsopolipus and Tarsopolipus from Iran. International Journal of Acarology $33,241-244$
Hall, I.M., Badgley, M.E., 1957. A rickettsial disease of larvae of species of Stethorus caused by Rickettsiella stethorae, n. sp.. Journal of Bacteriology 74, 452-455.

Harwood, J.D., Ricci, C., Romani, R., Obrycki, J.J., 2006a. Historic prevalence of a laboulbenialean fungus infecting introduced coccinellids in the United States. Antenna 30, 74-79.

Harwood, J.D., Ricci, C., Romani, R., Pitz, K.M., Weir, A., Obrycki, J.J., 2006b. Prevalence and association of the laboulbenialean fungus Hesperomyces virescens (Laboulbeniales: Laboulbeniaceae) on coccinellid hosts (Coleoptera: Coccinellidae) in Kentucky, USA. European Journal of Entomology 103, 799-804.

Haseeb, M., Murad, H., 1997. Susceptibility of the predator, Coccinella septempunctata to the entomogenous fungus, Beauveria bassiana. Annals of Plant Protection Science 5, 188-219.

Hochmuth, R.C., Hellman, J.L., Dively, G., Schroder, R.F.W., 1987. Effect of parasitic mite Coccipolipus epilachnae (Acari: Podapolipidae) on feeding, fecundity, and longevity of soybean-fed adult Mexican bean beetles (Coleoptera: Coccinellidae) at different temperatures. Journal of Economic Entomology 80, 612-616.

Hodek, I., 1973. Biology of Coccinellidae. Academia, Dr W. Junk, Prague, The Hague.

Hoogendoorn, M., Heimpel, G.E., 2002. Indirect interactions between an introduced and a native ladybird beetle species mediated by a shared parasitoid. Biological Control 25, 224-230.

Hurst, G.D.D., Purvis, E.L., Sloggett, J.J., Majerus, M.E.N., 1994. The effect of infection with male-killing Rickettsia on the demography of female Adalia bipunctata L. (two spot ladybird). Heredity 73, 309-316.

Hurst, G.D.D., Sharpe, R.G., Broomfiled, A.H., Walker, L.E., Majerus, T.M.O., Zakharov, I.A., Majerus, M.E.N., 1995. Sexually transmitted disease in a promiscuous insect, Adalia bipunctata. Ecological Entomology 20, 230-236.

Hurst, G.D.D., Hammarton, T.C., Obyrcki, J.J., Majerus, T.M.O., Walker, L.E., Bertrand, D., Majerus, M.E.N., 1996. Male-killing bacterium in a fifth ladybird beetle, Coleomegilla maculata (Coleoptera: Coccinellidae). Heredity 77, 177-185.

Hurst, G.D.D., Hammarton, T.M., Bandi, C., Majerus, T.M.O., Bertrand, D., Majerus, M.E.N., 1997. The diversity of inherited parasites of insects: the male-killing agent of the ladybird beetle Coleomegilla maculata is a member of the Flavobacteria. Genetics Research, Cambridge 70, 1-6.

Hurst, G.D.D., McMeechan, F.K., Majerus, M.E.N., 1998. Phoridae (Diptera) parasitizing Coccinella septempunctata (Coleoptera: Coccinellidae) select older prepupal hosts. European Journal of Entomology 95, 179-181.

Hurst, G.D.D., von der Schulenberg, J.H.G., Majerus, T.M.O., Bertrand, D., Zakharov, I.A., Baungaard, J., Volkl, W., Stouthamer, R., Majerus, M.E.N., 1999a. Invasion of one insect species, Adalia bipunctata, by two different male-killing bacteria. Insect Molecular Biology 8, 133-139.

Hurst, G.D.D., Bandi, C., Sacchi, L., Cochrane, A.G., Bertrand, D., Karaca, I., Majerus, M.E.N., 1999b. Adonia variegata (Coleoptera: Coccinellidae) bears maternally inherited Flavobacteria that kill males only. Parasitology 118, 125-134.

Hurst, G.D.D., Jiggins, F.M., von der Schulenberg, J.H.G., Bertrand, D., West, S.A., Goriacheva, I.I., Zakharov, I.A., Werren, J.H., Stouthamer, R., Majerus, M.E.N., 1999c. Male-killing Wolbachia in two species of insect. Proceedings of the Royal Society of London. Series B, Biological Sciences 266, 735-740.

Husband, R.W., 1984. The taxonomic position of Coccipolipus (Acarina: Podapolipidae), a genus of mites which are parasites of ladybird beetles (Coccinellidae). In: Griffiths, D.A., Bowman, C.E. (Eds.), Acarology, vol. 1. EllisHarwood Ltd., Chichester, pp. 328-336.

Hussain, K.J., Shanthi, R., Sanjayan, K.P., Muralirangan, M.C., 2006. Influence of weeds, natural enemy complex and abiotic factors on the population of Hennosepilachna vigintioctopunctata F. in a brinjal agroecosystem of Tamil Nadu. In: Ignacimuthu, S., Jayaraj, S. (Eds.), Biodiversity and Insect Pest Management. Narosa, New Delhi, pp. 346-353.

James, R.R., Croft, B.A., Shaffer, B.T., Lighthart, B., 1998. Impact of temperature and humidity on host-pathogen interactions between Beauveria bassiana and a coccinellid. Environmental Entomology 27, 1506-1513.

Joudrey, P., Bjørnson, S., 2007. Effects of an unidentified microsporidium on the convergent lady beetle, Hippodamia convergens Guérin-Méneville (Coleoptera: Coccinellidae), used for biological control. Journal of Invertebrate Pathology 94, $140-143$.

Kamburov, S.S., Nadel, D.J., Kenneth, R., 1967. Observations on Hesperomyces virescens Thaxter (Laboulbeniales), a fungus associated with premature mortality of Chilocorus bipustulatus L. in Israel. Israel Journal of Agricultural Research 17, 131-134.

Katsoyannos, P., Aliniazee, M.T., 1998. First record of Strongygaster triangulifera (Loew) (Diptera: Tachinidae) as a parasitoid of Harmonia axyridis (Pallas) (Coleoptera: Coccinellidae) in western North America. The Canadian Entomologist 130, 905-906.

Kenis, M., Roy, H.E., Zindel, R., Majerus, M.E.N., 2008. Current and potential management strategies against Harmonia axyridis. BioControl 53, 235-252.

Kitajima, E.W., Kim, K.S., Scott, H.A., Gergerich, R.C., 1985. Reovirus-like particles and their vertical transmission in the Mexican bean beetle, Epilachna varivestis (Coleoptera: Coccinellidae). Journal of Invertebrate Pathology 46, 83-97.

Knell, R.J., Webberley, K.M., 2004. Sexually transmitted diseases of insects: distribution, evolution, ecology and host behaviour. Biological Reviews 79 557-581.

Koch, R.L., Galvan, T.L., 2008. Bad side of a good beetle: the North American experience with Harmonia axyridis. BioControl 53, 23-35.

Koyama, S., Majerus, M.E.N., 2008. Interactions between the parasitoid wasp Dinocampus coccinellae and two species of coccinellid from Japan and Britain. BioControl 53, 253-264. 
Kuznetsov, V.N., 1997. Lady Beetles of the Russian far East. Memoir No. 1, Center for Systematic Entomology, The Sandhill Crane Press, Inc., Gainesville, FL, USA.

Majerus, M.E.N., 1994. Ladybirds. The New Naturalist. Harper Collins Publ., London.

Majerus, M.E.N., 1997. Parasitization of British ladybirds by Dinocampus coccinellae (Schrank) (Hymenoptera: Braconidae). British Journal of Natural History 10, 1524.

Majerus, M.E.N., 2006. The impact of male-killing bacteria on the evolution of aphidophagous coccinellids. European Journal of Entomology 103, 1-7.

Majerus, M.E.N., Majerus, T.M.O., 2000. Female-biased sex ration due to male-killing in the Japanese ladybird Coccinula sinensis. Ecological Entomology 25, 234-238.

Majerus, T.M.O., Majerus, M.E.N., Knowles, B., Wheeler, J., Bertrand, D., Kuznetzov, V.N., Ueno, H., Hurst, G.D.D., 1998. Extreme variation in the prevalence of inherited male-killing microorganisms between three populations of Harmonia axyridis (Coleoptera: Coccinellidae). Heredity 81, 683-691.

Majerus, M.E.N., Geoghegan, I.E., Majerus, T.M.O., 2000a. Adaptive preferential selection of young coccinellid hosts by the parasitoid wasp Dinocampus coccinellae (Hymenoptera: Braconidae). European Journal of Entomology 97, 161-164.

Majerus, M.E.N., Hinrich, J., Schulenberg, G.V.D., Zakharov, I.A., 2000b. Multiple causes of male-killing in a single sample of the two-spot ladybird, Adalia bipunctata (Coleoptera: Coccinellidae) from Moscow. Heredity 84, 605-609.

Majerus, M.E.N., Sloggett, J.J., Godeau, J.-F., Hemptinne, J.-L., 2007. Interactions between ants and aphidophagous and coccidophagous ladybirds. Population Ecology 49, 15-27.

Matadha, D., Hamilton, G.C., Hughes, M.G., Lashomb, J.H., 2003. Distribution of natural enemies of euonymus scale, Unaspis euonymi (Comstock) (Homoptera: Diaspididae), in New Jersey. Environmental Entomology 32, 602-607.

Nakamura, K., Ueno, H., Miura, K., 2005. Prevalence of inherited male-killing microorganisms in Japanese population of ladybird beetle Harmonia axyridis (Coleoptera: Coccinellidae). Annals of the Entomological Society of America 98, 96-99.

Nalepa, C.A., Kidd, K.A., 2002. Parasitism of the multicolored Asian lady beetle (Coleoptera: Coccinellidae) by Strongygaster triangulifera (Diptera: Tachinidae) in North Carolina. Journal of Entomological Science 37, 124-127.

Nalepa, C.A., Weir, A., 2007. Infection of Harmonia axyridis (Coleoptera: Coccinellidae) by Hesperomyces virescens (Ascomycetes: Laboulbeniales): role of mating status and aggregation behavior. Journal of Invertebrate Pathology 94 196-203.

Nalepa, C.A., Drea, J.J., Bryan, M.D., 1993. Release and establishment of Chilocorus kuwanae (Coleoptera: Coccinellidae) in North Carolina. Journal of Entomological Science 28, 287-290.

Nalepa, C.A., Kidd, K.A., Ahlstrom, K.R., 1996. Biology of Harmonia axyridis (Coleoptera: Coccinellidae) in winter aggregations. Annals of the Entomological Society of America 89, 681-685.

Okuda, T., Ceryngier, P., 2000. Host discrimination in Dinocampus coccinellae (Hymenoptera: Braconidae), a solitary parasitoid of coccinellid beetles. Applied Entomology and Zoology 35, 535-539.

Orr, C.J., Obrycki, J.J., Flanders, R.V., 1992. Host-acceptance behavior of Dinocampus coccinellae (Hymenoptera: Braconidae). Annals of the Entomological Society of America 85, 722-730.

Osawa, N., 1992. Effect of pupation site on pupal cannibalism and parasitism in the ladybird beetle Harmonia axyridis Pallas (Coleoptera: Coccinellidae). Japanese Journal of Entomology 60, 131-135.

Otsu, Y., Matsuda, Y., Shimizu, H., Ueki, H., Mori, H., Fujiwara, K., Nakajima, T., Miwa, A., Nonomura, T., Sakuratani, Y., Tosa, Y., Mayama, S., Toyoda, H., 2003. Biological control of phytophagous ladybird beetles Epilachna vigintioctopunctata (Col., Coccinellidae) by chitinolytic phylloplane bacteria Alcaligenes paradoxus entrapped in alginate beads. Journal of Applied Entomology 127, 441-446.

Own, O.S., Brooks, W.M., 1986. Interactions of the parasite Pediobius foveolatus (Hymenoptera: Eulophidae) with two Nosema spp. (Microsporida: Nosematidae) of the Mexican bean beetle (Coleoptera: Coccinellidae). Environmental Entomology 15, 32-39.

Pasteels, J.M., 2007. Chemical defence, offence and alliance in ants-aphidsladybirds relationships. Population Ecology 49, 5-14.

Peveling, R., Demba, S.A., 1997. Virulence of the entomopathogenic fungus Metarhizium flavoviride Gams and Rozsypal and toxicity of diflubenzuron, fenitrothion-esfenvalerate and profenofos-cypermethrin to nontarget arthropods in Mauritania. Archives of Environmental Contamination and Toxicology 32, 69-79.

Ping, S., Qin-Ying, W., Hui-Xian, Wu, Xiu-Jun, L., Yong, W., 2008. Identification of the cry gene in Bacillus thuringiensis strain WZ-9 and its toxicity against Henosepilachna vigintioctomaculata. Chinese Journal of Agricultural Biotechnology 5, 245-250.

Poprawski, T.J., Legaspi, J.C., Parker, P.E., 1998. Influence of entomopathogenic fungi on Serangium parcesetosum (Coleoptera: Coccinellidae), an important predator of whiteflies (Homoptera: Aleyrodidae). Environmental Entomology 27, 785795

Raju, K., Uma Maheswari, T., 2005. Natural enemies associated with spotted leaf beetle Henosepilachna vigintioctopunctata F. on Brinjal. Insect Environment 10, 168-169.

Riddick, E.W., 2006. Influence of host gender on infection rate, density and distribution of the parasitic fungus, Hesperomyces virescens, on the multicolored Asian lady beetle, Harmonia axyridis. Journal of Insect Science 6 (42), 1-15 (Available online: insectscience.org/6.42).
Riddick, E.W., Schaefer, P., 2005. Occurrence, density, and distribution of parasitic fungus Hesperomyces virescens (Laboulbeniales: Laboulbeniaceae) on multicolored Asian lady beetle (Coleoptera: Coccinellidae). Annals of the Entomological Society of America 98, 615-624.

Roy, H.E., Cottrell, T.E., 2008. Forgotten natural enemies: interactions between coccinellids and insect-parasitic fungi. European Journal of Entomology 105, 391-398.

Roy, H.E., Brown, P.M.J., Rothery, P., Ware, R.L., Majerus, M.E.N., 2008. Interactions between the fungal pathogen Beauveria bassiana and three species of coccinellid: Harmonia axyridis, Coccinella septempunctata and Adalia bipunctata. BioControl 53, 265-276.

Saito, T., Bjørnson, S., 2006. Horizontal transmission of a microsporidum from the convergent lady beetle, Hippodamia convergens Guérin-Méneville (Coleoptera: Coccinellidae), to three coccinellid species of Nova Scotia. Biological Control 39 427-433.

Saito, T., Bjørnson, S., 2008. Effects of a microsporidium from the convergent lady beetle, Hippodamia convergens Guérin-Méneville (Coleoptera: Coccinellidae), on three non-target coccinellids. Journal of Invertebrate Pathology 99, 294-301.

Santamaria, S., 1995. New and interesting Laboulbeniales (Fungi, Ascomycotina) from Spain, III. Nova Hedwigia 61, 65-83.

Santamaria, S., 2001. Los Laboulbeniales, un grupo enigmatico de hongos parasitos de insectos. Lazaroa 22, 3-19.

Schroder, R.F.W., 1979. Host specificity tests of Coccipolipus epilachnae, a mite parasitic on the Mexican bean beetle. Environmental Entomology 8, 46-47.

Schroder, R.F.W., 1982. Effect of infestation with Coccipolipus epilachnae Smiley (Acarina: Podapolipidae) on fecundity and longevity of the Mexican bean beetle. International Journal of Acarology 8, 81-84.

Schulenburg, J.H.G.V.D., Habig, M., Sloggett, J.J., Webberley, M., Bertrand, D., Hurst, G.D.D., Majerus, M.E.N., 2001. Incidence of male-killing Rickettsia spp. $(\alpha-$ proteobacteria) in the ten-spot ladybird beetle Adalia decempunctata L (Coleoptera: Coccinellidae). Applied and Environmental Microbiology 67, 270-277.

Shapiro-Ilan, D.I., Cottrell, T.E., 2005. Susceptibility of lady beetles (Coleoptera: Coccinellidae) to entomopathogenic nematodes. Journal of Invertebrate Pathology 89, 150-156.

Smith, L.M., Kok, L.T., 1983. Hyalomyodes triangulifer (Diptera: Tachinidae) parasitizes adults of Rhinocyllus conicus (Coleoptera: Curculionidae). The Canadian Entomologist 115, 1533-1534.

Sokolova, M.I., Zinkevich, N.S., Zakharov, I.A., 2002. Bacteria in ovarioles of females from maleless families of ladybird beetles Adalia bipunctata L. (Coleoptera: Coccinellidae) naturally infected with Rickettsia, Wolbachia, and Spiroplasma. Journal of Invertebrate Pathology 79, 72-79.

Tanada, Y., Kaya, H.K., 1993. Insect Pathology. Academic Press, Inc., San Diego, CA

Tavares, I.I., 1979. The Laboulbeniales and their arthropod hosts. In: Batra, L.R. (Ed.) Insect-Fungus Symbiosis: Nutrition, Mutualism, and Commensalism. John Wiley and Sons, New York, pp. 229-258.

Tavares, I.I., 1985. Laboulbeniales (Fungi, Ascomycetes). Mycologia Memoir 9. J. Cramer Publ., Germany.

Thaxter, R., 1931. Contribution towards a monograph of the Laboulbeniaceae. V. Memoirs of the American Academy of Arts and Sciences 16, 1-435.

Todorova, S.I., Coderre, D., Côte, J.C., 2000. Pathogenicity of Beauveria bassiana isolates toward Leptinotarsa decemlineata [Coleoptera: Chrysomelidae], Myzus persicae [Homoptera: Aphididae] and their predator Coleomegilla maculata lengi [Coleoptera: Coccinellidae]. Phytoprotection 81, 15-22.

Uma Devi, K., Padmavathi, J., Uma Maheswara Rao, C., Khan Akbar Ali, P., Mohan Murali, C., 2008. A study of host specificity in the entomophagous fungus Beauveria bassiana (Hypocreales, Clavicipitaceae). Biocontrol Science and Technology 18, 975-989.

Vargo, A., Schreiner, I., 2000. Philippine lady beetle (Epilachna viginsexpunctato (Boisduval)) and cucumber lady beetle (E. cucurbitae Richards). In: Agricultural Pests of the Pacific. Agricultural Development in the American Pacific, 2000-14.

Webberley, K.M., Hurst, G.D.D., 2002. The effect of aggregative overwintering on an insect sexually transmitted parasite system. Journal of Parasitology 88, 707712 .

Webberley, K.M., Buszko, J., Isham, V., Hurst, G.D.D., 2006. Sexually transmitted disease epidemics in a natural insect population. Journal of Animal Ecology 75 33-43.

Webberley, K.M., Hurst, G.D.D., Husband, R.W., Schelenburg, J.H.G.V.D., Sloggett, J.J. Isham, V., Buszko, J., Majerus, M.E.N., 2004. Host reproduction and a sexually transmitted disease: causes and consequences of Coccipolipus hippodamiae distribution on coccinellid beetles. Journal of Animal Ecology 73, 1-10.

Weir, A., 1996. A preliminary host-parasite list of British Laboulbeniales (Fungi, Ascomycotina). Entomologist 115, 50-58.

Weir, A., Beakes, G.W., 1995. An introduction to the Laboulbeniales: a fascinating group of entomogenous fungi. Mycologist 9, 6-10.

Weir, A., Beakes, G.W., 1996. Correlative light- and scanning electron microscope studies on the developmental morphology of Hesperomyces virescens. Mycologia 88, 677-693.

Weir, A., Blackwell, M., 2004. Fungal biotrophic parasites of insects and other arthropods. In: Vega, F.E., Blackwell, M. (Eds.), Insect-Fungal Associations: Ecology and Evolution. Oxford Press, New York, pp. 119-145.

Welch, V.L., Sloggett, J.J., Webberley, K.M., Hurst, G.D.D., 2001. Short-range clinal variation in the prevalence of a sexually transmitted fungus associated with urbanisation. Ecological Entomology 26, 547-550. 